\title{
Intergenerational equity, equality and reciprocity in economically and politically turbulent times: narratives from across generations
}

\author{
Josephine M. Wildman ${ }^{1 \star}$ (D), Anna Goulding ${ }^{1}$, Suzanne Moffatt ${ }^{1}$, Thomas Scharf ${ }^{1}$ \\ and Alison Stenning ${ }^{2}$ \\ ${ }^{1}$ Population Health Sciences Institute, Newcastle University, Sir James Spence Institute, Newcastle upon \\ Tyne, UK and ${ }^{2}$ Department of Geography, Politics and Sociology, Newcastle University, Newcastle upon \\ Tyne, UK \\ *Corresponding author. Email: josephine.wildman@ncl.ac.uk
}

(Accepted 22 December 2020; first published online 22 February 2021)

\begin{abstract}
The concept of intergenerational fairness has taken hold across Europe since the 2008 financial crisis. In the United Kingdom (UK), focus on intergenerational conflict has been further sharpened by the 2016 'Brexit' vote to take the UK out of the European Union. However, current debates around intergenerational fairness are taking place among policy makers, the media and in think-tanks. In this way, they are conversations about, but not with, people. This article draws on qualitative interviews with 40 people aged 19-85 years and living in North-East England and Edinburgh, Scotland's capital city, to explore whether macro-level intergenerational equity discourses resonate in people's everyday lives. We find widespread pessimism around young people's prospects and evidence of a fracturing social contract, with little faith in the principles of intergenerational equity, equality and reciprocity upon which welfare states depend. Although often strong, the kin contract was not fully ameliorating resentment and frustration among participants observing societal-level intergenerational unfairness mirrored within families. However, blame for intergenerational inequity was placed on a remote state rather than on older generations. Despite the precariousness of the welfare state, participants of all ages strongly supported the principle of state support, rejecting a system based on family wealth and inherited privilege. Rather than increased individualism, participants desired strengthened communities that encouraged greater intergenerational mixing.
\end{abstract}

Keywords: intergenerational relations; generations; austerity; Brexit; family relationships

\section{Introduction}

The concept of intergenerational fairness, prominent in the United States of America (USA) for over 30 years, has rapidly taken hold across Europe since the 2008 global financial crisis (Kohli, 2006; Bristow, 2016; Alexander Shaw, 2018). Among the political class and in the realm of think-tanks and the media',

(C) The Author(s), 2021. Published by Cambridge University Press. This is an Open Access article, distributed under the terms of the Creative Commons Attribution licence (http://creativecommons.org/licenses/by/4.0/), which permits unrestricted re-use, distribution, and reproduction in any medium, provided the original work is properly cited. 
economic pain is explained in terms of intergenerational conflict (Alexander Shaw, 2018: 20; Resolution Foundation, 2018; House of Lords, 2019), with a-poorly defined-older generation standing accused of hoarding resources and stealing the futures of a younger generation. In the United Kingdom (UK), the focus on intergenerational conflict has been further sharpened by the 2016 vote to leave the European Union (EU) (popularly termed 'Brexit'), widely characterised as a schism between older, socially conservative, and younger, progressively liberal, generations (NatCen, 2017). Yet, despite increasingly strident rhetoric, current intergenerational conflict debates are largely conversations about, but not with, people (Alexander Shaw, 2018), and this qualitative study asks whether higher-level narratives of intergenerational conflict are reflected in the everyday lives of people living in two regions in the north of the UK. In the following sections, we review the current state of the intergenerational social contract and describe how this study operationalises the slippery concept of generations.

\section{State of the social contract}

Across Europe, the economic consequences of the 2008 financial crisis - rising unemployment and stagnating wages combined with inflating asset prices and significantly reduced public spending - have impacted heavily on younger people (Cribb et al., 2017; European Commission, 2017; Resolution Foundation, 2019). In contrast, older people have, on average, been better protected, in part due to their position in the lifecourse - stagnating wages have less impact on those outside the labour force and the robust performance of asset values (particularly housing) benefits those who own their homes mortgage-free - but also due to political decisions to target economic austerity measures at working-age and family benefits while protecting older adults' entitlements (e.g. the state pension) (Tucker, 2017). However, although more older people are entering retirement with wealth and resources, in the UK a substantial minority continue to live on incomes below 60 per cent of median household income (after housing costs). According to this measure, 16 per cent of people over state pension age were living in poverty in 2018/19 (Age UK, 2018; Department for Work and Pensions, 2020). Moreover, income inequalities for individuals in retired households have increased in recent years (Office for National Statistics, 2019). The intersection of ageing, social class, gender and ethnicity over the lifecourse affects people at greatest risk of poverty in retirement, including tenants in both private and socially rented accommodation, people from Black, Asian and Minority Ethnic groups, and women, particularly older single women and those aged over 80 (Age UK, 2018).

Intergenerational redistribution of resources through taxation and spending is part of a social contract that depends for its legitimacy on the principles of reciprocity (mutual support between generations), equity (relation between inputs and outputs for one generation) and equality (corresponding conditions for different generations) (Svallfors, 2008; Prinzen, 2017). However, 'structural contradictions' exist for younger people between expectations of a generational contract, whereby older generations are supported by younger generations, and the belief that the same level of support will be unavailable in their own old age (Prinzen, 2014: 434). Moreover, a central tenet of the social contract is that each generation 
will improve on the fortunes of the last. The UK is particularly notable among highincome countries for the extent of intergenerational 'boom and bust' that has seen a recent and rapid reversal in young people's fortunes compared to those of their parents (Rahman and Tomlinson, 2018). In the UK, people pessimistic about young adults' chances of improving on their parents' lives in relation to access to pensions, housing and work outnumber optimists by two to one - a dramatic change from 2003 when optimists outnumbered pessimists four to one (Resolution Foundation, 2018).

'Claimsmakers' invoke generational divisions to a variety of ends (White, 2013; Bristow, 2020). The financial costs imposed by population ageing are widely assumed to pose a dire threat to the continued existence of the welfare states of economically developed countries (Kendig et al., 2019). In 2017, the European Commission's annual review of employment and social developments in Europe (European Commission, 2017) warned that failing to address age-based disadvantages risked undermining intergenerational social cohesion and support for welfare spending. Christophers (2018: 111) identifies a 'toxic' solution to intergenerational inequity that views welfare-state redistribution as the problem. The 'greedy geezers' of the baby-boom generation are deployed to disrupt the belief that older generations both deserve and require support due to their past contributions and greater economic and physical vulnerability (Kendig et al., 2019; Bristow, 2020). White (2013) warns that 'generationalism', defined by Purhonen (2016: 102) as a simplified and exaggerated view of generations that instigates artificial confrontations between the "generations"', has become a master narrative for reshaping the welfare state. By breaking down society into generations, welfare-state reformers can construct a demographic imperative that assumes that welfare spending is a burden placed by the old on the young (Williamson et al., 2003; White, 2013; Savage, 2014). The simplicity of a narrative that characterises older people as a (privileged) homogenous group ignores their growing diversity and multiple contributions. As such, the narrative is fundamentally flawed. Evidence points to the significant contribution to society (and the economy) made by older people via paid work, consumption, informal care, child care and volunteering (International Longevity Centre, 2020). The economic value of these activities far outweighs the amount spent on social care (Age UK, 2014), countering narratives of older people as simply 'consumers' of state resources (International Longevity Centre, 2020). This is a pattern replicated around the world. However, between 2009 and 2017, narratives of intergenerational (in)equity as a rationale for cutting social expenditure in Australia had little impact on perceptions of intergenerational conflict (Kendig et al., 2019).

While previous research finds no evidence of intergenerational conflict at the individual level (Kohli, 2006; Scharf et al., 2013; Shrimpton et al., 2017), some recent studies have reported generational tensions. A US study found that while people aged 20-36 continued to support redistribution of resources towards older people, this support co-existed with a sense of injustice that the social contract was being violated by demographic changes (Prinzen, 2017). Further, there is evidence that in countries with high levels of income inequality, such as the UK and the USA, older people are viewed by younger people as a greater threat to their financial welfare (Ayalon, 2019). In addition to what Ayalon (2019) terms this realistic threat, there is evidence of a symbolic threat from generational differences in 
world-view, belief systems and values. Much is made of political allegiances dividing along age lines (Prosser et al., 2018). For example, among young first-time voters in the 2017 UK general election, the (centre-left) Labour Party was 47 percentage points ahead, with the (centre-right) Conservative Party 50 percentage points ahead among voters aged over 70 (YouGov, 2017). Votes in the 2014 Scottish independence referendum and the UK Brexit vote were also presented as dividing along lines of age-based world-views: younger people broadly voted for the 'progressive' options of Scottish independence and remaining within the EU, while older people tended to vote for the 'conservative' options of Scotland remaining within the UK and taking the UK out of the EU (Ayres, (2014); Dalzell, 2017; YouGov, 2017). However, a closer study of Scottish independence referendum voting behaviour according to various demographics showed that voters aged 70 and above and those aged 16-24 were both more likely to vote 'no' to independence (Henderson and Mitchell, 2015). Further, although Brexit is presented in certain sections of the UK media as the theft of younger generations' future by older voters, voting patterns also divided along social class, education and ethnicity lines, with middle-class, more highly educated and Black and Minority Ethnic voters choosing to remain in the EU while working-class, less-educated and White voters chose to leave (Skinner and Gottfried, 2016). Party-political allegiances in the UK are also strongly correlated with education level: those educated to degree level or above (most likely to be younger people due to the recent rapid expansion of higher education) are far more likely to vote for left/centre-left parties, while those with no or low-level qualifications (more likely to be older people) are more likely to vote for right/centre-right parties (YouGov, 2019).

\section{Generations as a social category}

Despite its increasing ubiquity, 'generation' is a notoriously imprecise concept (Vincent, 2005; Carney et al., 2014). Mannheim (1952), in his seminal theoretical work, described three elements that constitute a generation: shared temporal location; shared historical location; and shared socio-cultural location. Definitions of a generation can, therefore, be grouped into (at least) three categories: the micro-level of family lineage; the macro-social level of age groups or cohorts; and historical generations who developed a collective consciousness during periods of rapid social change (e.g. the war generation, the 1960 s youth, etc.). Intergenerational fairness debates frequently treat generations as synonymous with age cohorts, e.g. 'millennials' are ranged against 'baby-boomers'. Although analytically convenient, this approach risks creating categories that, while bounded and concrete, lack meaning, with a label of 'generation' applied from above rather than arising from the actions and/or consciousness of people (Bristow, 2016). In this study, rather than clearly delineated groups, we consider generations as discourses (Scherger, 2012; Timonen and Conlon, 2015). Generations as 'discursive constructs' (Scherger, 2012; Foster, 2013; Timonen and Conlon, 2015) are explained by Scherger (2012: 11) as narratives that seek to make sense of the 'contemporaneity of, and conflicts between people born at the same time'.

Over 10 years into post-recession austerity and post-Brexit, this study makes a number of contributions to current intergenerational inequity debates. The study 
explores individuals' perceptions of giving and receiving support within the family and at the societal level. Here we treat generations as a tool for exploring what people 'think, say and do' about intergenerational fairness (Foster, 2013), seeking to understand how individuals perceive the 'problem' of intergenerational fairness, assign blame and perceive solutions (Alexander Shaw, 2018). We seek the views of people in the different policy contexts of England and Scotland brought about by regional government devolution in the UK. There are important policy differences in England and Scotland that may impact on perceptions of intergenerational fairness; e.g. higher education, social care and prescription medication are all free at the point of use for all age groups in Scotland. In England, higher education is funded by a loans system, prescriptions are free only for those under 16 or over 60 (and a limited number of low-income working-age adults) and social care is strictly means-tested.

\section{Data and methods}

We undertook a qualitative study using individual semi-structured interviews. To capture experiences in different policy contexts, participants were drawn from two geographical locations: Tyne and Wear, a region in North-East England, and Edinburgh, Scotland's capital city, selected because they encapsulated these differing policy contexts, but also pragmatically because the research team had access to a range of participants via networks with gatekeeper organisations in each locality. Both demographic data and data on voting behaviour were collected. Drawing on the approach used in the 'Changing Generations' study in Ireland (Timonen et al., 2013), we developed a topic guide organised around the concept of 'give and take' at different lifestages. Questions were framed in terms of lifestages due to the multiple possible interpretations of generation. Two initial questions enquiring about current stage of life and close family and friends intended to orientate participants to the study. Participants were then asked to talk about support they gave and received at two levels: firstly, at the individual level within their own family and community, and secondly, at the societal level in the state's role in providing support at different stages of life. For this study, and in terms of contributing to society and receiving from the state, and reflecting the particular context of the UK, participants were also asked about how they felt the vote to leave the EU would impact on them at their current lifestage.

\section{Sampling, data collection and analysis}

Ethical approval was secured from Newcastle University Faculty of Medical Science Ethics Committee. Sampling and recruitment aimed to maximise diversity along the lines of age and socio-economic status (indicated by employment status). Community-based sampling strategies were used for recruitment, including convenience and snowball sampling. Selected locations included a community arts café in an area of severe socio-economic deprivation; a men's group in a low-income area; a parent and child group in a middle- to low-income area; and home-owners in a private supported housing development reserved for people aged 60 and over in an area experiencing rapid gentrification. 
Interviews were conducted by three members of the study team between October 2017 and April 2018. Data collection and analysis were conducted simultaneously. Written informed consent was obtained prior to interview. Interviews were audiorecorded and transcribed verbatim. Transcripts were anonymised and names used here are pseudonyms. Line-by-line analysis was used to identify and code themes emerging from the data. Analysis of the interview data was iterative and ongoing, using a constant comparative method, where data from each new interview were compared with data from previous interviews (Charmaz, 2003). Cross-sectional coding was used to create a common system of codes across the dataset (Ritchie et al., 2014). The study team met regularly to discuss themes emerging from the data. As the interviews progressed, a theoretical sampling approach was adopted, enabling exploration of themes arising from the initial interviews (Charmaz, 2006). For example, we found that socio-economic status was not as closely associated with perceptions of generational struggle as previous studies have suggested (e.g. Carney et al., 2014). Instead, lifestage appeared to have more influence in this sample and, therefore, later sampling focused on recruiting working-age participants. In total, 40 interviews were conducted: 24 in Tyne and Wear and 16 in Edinburgh. Table 1 summarises the achieved sample. Participants ranged in age from 19 to 85 years. Despite their relatively high levels of educational attainment, most participants recruited in Tyne and Wear were (or, if retired, had been) employed in lower occupational status work or economically inactive $(\mathrm{N}=17)$. Nearly half were in low-income households $(\mathrm{N}=11)$. Just over half of the Edinburgh sample were in lower occupational status work $(\mathrm{N}=9)$. However, probably reflecting Edinburgh's relative affluence, fewer participants (just over a third) were in low-income households.

\section{Findings}

Three main themes emerged from the data: (a) the fragility of the state-level intergenerational social contract and the range of challenges facing younger people, but also a 'struggling middle' and older people requiring care; (b) the political becoming personal within families where the fracturing social contract and differing world-views were creating frustration and resentment; and (c) blame assigned not to older generations but to a 'socially ignorant' state.

\section{The state of the social contract}

Participants shared the pessimism surrounding younger people's prospects identified among the wider public (Resolution Foundation, 2018). The state was judged to be failing young people and a wide range of sites of vulnerability were identified (Dumas and Turner, 2009):

I think that lack of support to the 16-35 age group is gigantic - whether that's in benefits, tax breaks, minimum wage, access to further and higher education, access to decent paid, secured jobs, housing, you name it. I think they are disproportionately affected in the most negative way. (Edith, aged 58, Edinburgh) 
Table 1. Interview participant characteristics

\begin{tabular}{|c|c|c|}
\hline & $\begin{array}{l}\text { Tyne and } \\
\text { Wear }\end{array}$ & Edinburgh \\
\hline $\mathrm{N}$ & 24 & 16 \\
\hline Age range & $19-81$ & $23-85$ \\
\hline \multicolumn{3}{|l|}{ Gender: } \\
\hline Male & 7 & 5 \\
\hline Female & 17 & 11 \\
\hline \multicolumn{3}{|l|}{ Marital status: } \\
\hline Married/co-habiting/civil partnership & 16 & 9 \\
\hline Single & 5 & 3 \\
\hline Divorced/separated & 2 & 1 \\
\hline Widowed & 1 & 3 \\
\hline \multicolumn{3}{|l|}{ Highest qualification level: } \\
\hline No formal qualifications & 1 & 2 \\
\hline O-level or equivalent & 6 & 2 \\
\hline A-level or equivalent & 4 & 1 \\
\hline Degree level or above & 13 & 11 \\
\hline \multicolumn{3}{|l|}{ Occupational social class: } \\
\hline 1. Large employer and higher managerial/professional & 1 & 2 \\
\hline 2. Lower professional/managerial and higher supervisory & 4 & 3 \\
\hline 3. Intermediate & 1 & 1 \\
\hline 4. Small employer and own account worker & 1 & 1 \\
\hline 5. Lower supervisory/technical & 9 & 2 \\
\hline 6. Semi-routine & 2 & 4 \\
\hline 7. Routine & 1 & 0 \\
\hline $\begin{array}{l}\text { 8. Never worked/long-term unemployed and caring home/ } \\
\text { family }\end{array}$ & 3 & 3 \\
\hline Student & 2 & 0 \\
\hline \multicolumn{3}{|l|}{ Household income (£1,000s) } \\
\hline$<20$ & 11 & 6 \\
\hline $20-34$ & 5 & 6 \\
\hline $35-55$ & 5 & 2 \\
\hline$>55$ & 3 & 2 \\
\hline \multicolumn{3}{|l|}{ Home-ownership status: } \\
\hline Own outright & 7 & 9 \\
\hline Own with mortgage & 8 & 1 \\
\hline
\end{tabular}


Table 1. (Continued.)

\begin{tabular}{lcc}
\hline & $\begin{array}{c}\text { Tyne and } \\
\text { Wear }\end{array}$ & Edinburgh \\
\hline Renting privately & 7 & 4 \\
\hline Renting social housing & 1 & 1 \\
\hline Living at home/lodging & 1 & 1 \\
\hline EU membership referendum vote: & 21 & 13 \\
\hline Remain & 0 & 3 \\
\hline Leave & 3 & 0 \\
\hline Didn't vote/prefer not to say & & 6 \\
\hline Scottish independence referendum: & n/a & 10 \\
\hline No (remain in the UK) & n/a \\
\hline Yes (leave the UK) & & \\
\hline
\end{tabular}

Notes: EU: European Union. UK: United Kingdom. n/a: not applicable.

The adjective 'scary' was frequently applied to the future. Fears focused around young people's later-life prospects and the need for self-reliance in a system where the principle of intergeneration equity (correspondence between inputs and outputs) could not be relied upon. Younger participants, including 36-year-old self-employed Isla (Edinburgh), doubted the continued existence of the state pension in their own old age:

Why have I not got a private pension? That's scary. But, I am paying my National Insurance Contributions. Come on government! That's so naïve though, isn't it? [The state pension] is not going to be there. There's going to be nothing.

Also frequently identified was the devaluing of educational qualifications due to the rapid expansion of higher education, without a corresponding increase in the expansion of graduate jobs: young graduates were being prepared for a working future promising high-skilled, personally and financially rewarding work that, for many, appeared unattainable. The absence of structures, such as good-quality employment, required to achieve adulthood was creating a limbo of extended adolescence and delayed independence. Recently graduated Alex (aged 23, Edinburgh) observed:

[N] early 24 is the age I am. That's the age, there's no way anymore that you're supposed to be a child at all, you're supposed to be an adult in charge of your responsibilities and doing things ... It seems like there's a whole load of expectations about what young people are or should be or should be aiming towards and actually for the vast majority [it] is not attainable.

Moreover, by imposing age-based rules on entitlements (e.g. restrictions on housing support for those aged under 35), the state was formalising what Heather (aged 24, 
Edinburgh), another recent graduate, called a 'prolonged adolescence'. Participants of all ages felt that a lack of support and an uncertain future were severely impacting on younger people's mental wellbeing. Bridget (aged 85, Edinburgh), who recalled the struggles of the young during the war, felt modern life presented its own challenges:

I would say the past 20 years, generally, [life for young people] has gradually got more and more difficult ... I think it's terrible when young people are so upset with life that they commit suicide.

While younger people were judged to be most affected by a failing state, a further 'forgotten' group of 'people in the middle' were identified, who once 'taking care of themselves ... and supposedly getting by, are not getting by anymore' (Mark, aged 65 , Tyne and Wear). A range of vulnerabilities were also identified among this group. The relatively rapid alignment of men and women's state pension ages in the UK has been identified as creating hardship and resentment among women in their late fifties and early sixties (Lain et al., 2019). After more than 40 years in employment, Cathy (aged 61, Tyne and Wear) articulated a sense of unfairness shared by other women her age - at the removal of the option to retire on a state pension at age 60:

I resent that the choice [to retire] has been taken away I think, that really chews me off a little bit ... I think it's not fair after all these years working towards something that was taken away just like that.

Other participants had encountered ageism among employers and policy makers, with older people excluded from the labour market. Alice (aged 56, Tyne and Wear), who had experience helping older workers find work, concluded that: 'after 25 you can go and hang yourself really because there is no real money ... I'm talking about training [for] the over fifties'. After leaving work to care for her mother, the extended state pension age had left Grace (aged 58, Tyne and Wear) too young to retire but seemingly too old to be considered for paid work. She felt 'invisible in the workplace at my age ... I haven't left one base uncovered and I still can't get back into the world of employment'. At all ages, there was concern about the poor state of care available for older people, with Lisa's (aged 42, Edinburgh) experiences capturing a common attitude:

I've worked in nursing homes and they're horrific ... I've worked in loads and even the good ones, the way the residents are treated is awful, considering people are waiting there to die ... I wouldn't wish it on anyone ... I wouldn't do that to my parents.

Like Lisa, many younger participants were adamant that, if required, they rather than the state would care for their elderly parents. However, for those, like Grace, in their fifties and sixties and caring for older family members, little support was available and caring could be intensely physically, emotionally and financially demanding, with some reporting having to either give up their employment or radically reduce their working hours in order to cope. 
Scottish and English regional policy differences appeared to have little impact on participants' fears: although ostensibly free at the point of delivery in Scotland, university living costs and the poor state of social care were still of concern to Edinburgh participants.

\section{The political becoming personal}

Participants most closely experienced intergenerational relationships at the level of the family. Ties of duty and affection could be strong between family generations, with the familial welfare state, for many, upholding the principle of intergenerational reciprocity absent from the state-level social contract. Financial, practical and emotional support was flowing up, down and across the family generations, altering according to need and stage of life. Older participants helped out with adult children's university costs and housing deposits - and, for some, the everyday costs of living - while younger participants cared for their own young children and/ or ageing parents.

Nevertheless, kinship bonds - even when strong - were not entirely ameliorating the potential for intergenerational tension within families. Delayed independence affecting adult children had left some parents conflicted over the necessity of continuing to provide financial support:

...you resent it, you love your children, don't get me wrong ... [but] there is a resentment there ... you don't count the pennies when it's your kids but you always know that you're struggling, especially as you get into your fifties when your health starts to go a bit and you haven't got the energy you had. You kind of thought, 'I want a bit of peace', but then you're worried about what's going to come around the corner. (Alice, aged 56, Tyne and Wear)

Conflicted emotions of affection and resentment were shared by participants approaching retirement age and experiencing a delay in a much-anticipated 'third age' period of freedom.

Among some, the language of 'generationalism' - an exaggerated, often derogatory view of generations - was evident. One step removed at the societal level, the violation of the principle of intergenerational equality (corresponding conditions for different generations) was experienced directly at the family level. Some younger participants identified their parents as members of the 'baby-boomer' generation, judged to 'benefit very well from the type of economy that we live in' (Alex, aged 24, Edinburgh). What Fiona (aged 36, Edinburgh) termed the 'very lucky generation' had in Isla's (aged 36, Edinburgh) view 'actually been really well padded as a generation. I anticipate that we are going to be far less catered for as an older generation than our parents have been'. Like Fiona, Ben (aged 50, Tyne and Wear) described feelings of frustration over the relative (rather than absolute) positions of himself and his parents:

Ben: $\quad$...the older generation now have had it easier than we're going to have it, moving into the pensions and benefits and all that type of thing ... I don't think I'm going to be able to retire at 55 like I'd 
love to, even though I've worked by the time I get there, 40 years or whatever.

Interviewer: How do you feel about that?

Ben: $\quad$ I suppose a bit angry in some ways, but only because I've seen my parents' generation be able to do it ... but it's a lot harder to do that type of thing now. But if I haven't seen them be able to do that, then my lot's pretty good at the minute, but I've seen that it could've been so much better ... So, I don't know, but it does get your goat a little bit ... [we] work as hard, we're going to work longer and we're not going to get as much as the previous generation did and they didn't do any more than we have.

The vote to leave the EU was widely viewed as occurring along generational lines. While the older 'Brexit generation', motivated by self-interest, had voted to leave the $\mathrm{EU}$, the impact of the vote was judged to fall on the young, violating the principles of intergenerational reciprocity and equality:

I felt like some of the older generation just didn't think about the people in their family. I just feel like the old generation have got their money and they're set, whereas us guys who are trying to get a house and trying to get established ourselves are the ones who are going to be impacted. (Rebecca, aged 36, Tyne and Wear)

Differences in voting behaviour over Brexit meant the political had become personal within some families, with expressions of anger and betrayal over older family members' voting choices. Younger participants keenly felt the loss of their status as Europeans and the opportunities they felt this afforded them. Ingrid (aged 41, Tyne and Wear) described a schism between her socially liberal world-view and her parents' more socially conservative views:

Interviewer: Did your parents discuss with you why they voted to leave the EU? Ingrid: $\quad$...I think, if I'm honest, I think my parents just thought, 'Well we'll have less foreign people in this country if we vote out.' I think they've got quite some old-fashioned views on that, whereas I quite like all the diversity ... I don't want to live in a place where it's all White British people, but from my parents' generation, that's exactly what they want ... We've had so many arguments about it.

The more restrained anger around generational differences in access to economic resources (expressed in terms like 'a bit annoyed') had, for some, become far stronger.

\section{Assigning blame and seeking solutions}

In response to perceptions of intergenerational unfairness, there was some appetite for redistribution in a system that Colin (aged 26, Tyne and Wear) felt 'tends to 
sway more towards the older generations getting more support than the younger'. However, where such views were expressed, this was at the margins of social spending, e.g. ending free bus travel for people aged 60 and above was mentioned. The sense of intergenerational injustice had largely not translated into a desire to strip older people of their welfare entitlements. Indeed, state spending was judged to be insufficient across all generations. Blame for the broken social contract was attributed not to other generations, but to what Grace (aged 58, Tyne and Wear) termed the 'social ignorance' of successive governments who failed to appreciate how their policies would impact differently on different people's lives. Colin blamed this social ignorance for the distribution of resources towards older people, regardless of need:

...the people who are responsible for putting support services in place need to look at the real picture rather than just seeing that the older generation are older, so they need this. Realising what zero-hour contracts and temporary contracts and apprenticeship wages actually means in real-life terms and what it means to an individual on a day-to-day basis.

Suggesting that generation as a social category complements rather than replaces social class (Christophers, 2018), participants were keenly aware of intragenerational socio-economic inequalities at all ages: graduate jobs were 'available to a very select few' (Alex, aged 23, Edinburgh), while among older people 'there's a lot with just their state pension and then rely on benefits' (Dora, aged 75, Edinburgh). Reliance on family resources in the absence of the state was commonly viewed as exacerbating within-generation socio-economic inequalities. Participants were acutely aware of the unfairness and unsustainability of a social support system built upon family resources. Particularly among participants lacking the financial resources to offer support to their family, the future could appear bleak:

...although we've got no savings and no assets because we're basically working class, almost poverty-like people, my property is what's going to save me from the workhouse. My son's not going to have that. He's also not going to inherit, like I've never inherited property. He's not going to inherit, because I have to live on it. But he can't get on the housing ladder ... my heart breaks for him, because there's no money in our family. (Grace, aged 58, Tyne and Wear)

Far from supporting the dismantling of the welfare state, participants shared a desire for community and greater-grass-roots - collectivism that, importantly, complemented rather than replaced state spending. Moreover, many participants referred to the importance of intergenerational mixing within communities to promote understanding between generations, especially in the aftermath of the vote to leave the EU. Reflecting on the older people she had met through her work, Florence (aged 29, Tyne and Wear) concluded:

I do think there's an issue with 'them and us' as well. We're all people together and I think maybe if there was a little bit more mingling between the generations, we'd just see each other as people and not like 'oh they're in this category and this 
category', and maybe it would actually help people to understand each other a bit better.

For some, an alternative to a less 'socially ignorant' model was presented by the devolved Scottish government. Although participants in Edinburgh shared many of the anxieties of those in Tyne and Wear, the social contract was largely judged to be stronger in Scotland than England. The government in Scotland was perceived as being closer to its citizens, more responsive to their needs and more socially just than the Westminster government. Like a number of Edinburgh participants, Clare (aged 53, Edinburgh) identified the Westminster government's 'social ignorance' of the reality of people's lives outside London as motivating her to vote for an independent Scotland:

I would like Scotland to have independence ... I would like all different parts of the country to have their independence. I think there are too many decisions made by London. I don't think they realise how difficult it is for some people, I really don't. They're not living the lives that people are living here and other parts of the country.

Notably, the Scottish independence referendum had strengthened participants' faith in the democratic process, engendering feelings of inclusion in the political discourse especially among younger participants. Graham (aged 23, Edinburgh) described his experiences of voting in the independence referendum:

People actually had legitimate arguments about it and didn't just scaremonger ... It was just a much nicer atmosphere. There was discussion. Like when you'd get into a referendum discussion it would get heated sometimes, but it was still informed and clear on both sides and with legitimate concerns either way, which was really nice. The Scottish referendum was good.

This was in sharp contrast to the Brexit referendum, which was widely characterised as divisive and based on 'lies'.

\section{Discussion}

This study reveals discourses taking place beneath the headline rhetoric of intergenerational unfairness (Alexander Shaw, 2018). While the familial welfare state was often generous in its support, we find that family ties of affection were not fully ameliorating feelings of resentment among participants observing societal-level intergenerational unfairness mirrored within their own families. The intergenerational inequity problem is most frequently framed in terms of conflict or solidarity. Yet, it is plausible that an individual will experience both. A number of recent sociological writings have sought to address this tension by developing the concept of intergenerational 'ambivalence': simultaneous conflict and solidarity (Pillemer et al., 2007; Hillcoat-Nallétamby and Phillips, 2011; Park, 2014; Prinzen, 2014).

As reflected in our findings, shared norms around the deservingness of support of vulnerable older people and inter-family cohesion and affection tend to positive 
views of older generations while self-interest and perceptions of unfairness tend to negative views (Prinzen, 2014). Here, ambivalence is reflected in the language of restrained anger used by participants to articulate their frustrations. Intergenerational ambivalence is suggested to be a symptom of a shift in established social structures, resulting in reality running counter to expectations (Hillcoat-Nallétamby and Phillips, 2011), e.g. our finding of young adults' frustration at their inability to achieve independence from their parents and parents' frustrations at the necessity of providing for their adult children.

Timonen and Conlon (2015) argue that intergenerational inequity is a 'smokescreen' that distracts from class inequity, and increasingly masks the influence of intersecting identities (Holman and Walker, 2020). We contend that, while not replacing or minimising social class, gender or ethnicity as a determinant of advantage, generations provide an additional social category for the analysis of inequalities (Dumas and Turner, 2009; Christophers, 2018), with greater or lesser opportunities for economic success imbuing generations with a class-like character (Vincent, 2005). Kendig et al. (2019) observe that economic shocks and shifting political ideologies mean that advances made by earlier cohorts are far less achievable for subsequent cohorts. We find little faith in the belief that each generation will be better off than the last and a lack of faith in the principles of intergenerational reciprocity, equity and equality that underpin the state social contract. Younger people in particular faced uncertain futures, lacking the ingredients that enabled previous generations to 'get on' in life, e.g. good jobs, rising incomes, home-ownership and decent pensions, echoing the 'stark pessimism about future entitlements' found by Timonen et al. (2013: 175) amongst Irish citizens of all ages. We find evidence of contradictions between the values and ideals that young people receive (e.g. education, independence, self-achievement and rewarding work) and the realities they face (centrality of the market, heteronomy and a lack of valuable jobs) - what Chauvel (2006) terms 'dyssocialization'.

Among this study's participants, intergenerational inequalities are relative rather than absolute, with all but the oldest comparing their own positions unfavourably to those of previous generations. In the context of the rapid relative decline in younger people's circumstances, post-financial crisis sociological writings have approached the 'problem' of generations as one of thwarted expectations (Savage, 2014; Christophers, 2018). For Mannheim (1952: 294), an important feature of generations was the continuous emergence of new age groups, engaging with the heritage of preceding generations and coveting 'that which is yet to be won'. Similarly, for Bristow (2016: 7) the problem of generations is a knowledge problem; that is, how knowledge about the past shapes expectations about the future and 'the potentially fraught relationship between traditional social norms and values and expectations of a younger generation growing up during a period where such norms have recently been shattered'. Timonen et al. (2013: 177) identified 'generational observing' to denote intergenerational processes at the family level and recognise that intergenerational solidarity 'evolves as family generations observe each others' practices and adjust their expectations accordingly', foregrounding the ways in which available socio-economic resources and welfare state policies shape attitudes and practices towards other generations. 
To understand intergenerational inequalities in terms of economic structures and frustrated expectations is to identify potential solutions, while rejecting others. This study's participants recognise the old patterns of familial wealth as, once again, a central determinant of life chances (Savage, 2014). The role of family generations and their potential impact on both inter- and intragenerational inequalities is receiving particular attention in economically challenging times (Peugny and Van de Velde, 2014). In the 'Changing Generations' study, Timonen et al. (2013) identified the intergenerational resourcing of children within families as perhaps the most important determinant of life chances in post-recession Ireland. Scholars in the field of intergenerational relations have argued for the ameliorating effects of intra-family affection and obligations on intergenerational conflict (Dumas and Turner, 2009; Carney et al., 2014). Transfers of financial resources down familial generations, what Carney et al. (2014) term the 'familial welfare state', are proposed as buffers against the negative effects of economic changes (Bengtson and Putney, 2006; Carney et al., 2014). Yet, while intra-family transfers of resources are suggested to mitigate intergenerational unfairness (Keohane, 2016), we identify a widespread rejection of a system based on family wealth and inherited privilege. Intra-family transfers of wealth are viewed here, as Peugny and Van de Velde (2014) predicted, as increasing both inter- and intragenerational inequality at the societal level.

Although we find evidence of resentment of the benefits enjoyed by older generations (and especially the 'lucky' baby-boomer generation), there is no generation war. Instead, there is an awareness of the 'alternative causal stories' beyond a selfinterested, unfairly resourced older generation (Alexander Shaw, 2018). Participants placed the blame for intergenerational inequity not on older generations, but rather on a remote state, 'socially ignorant' of the realities of the lives of people of all ages. Far from supporting the rolling-back of the state and increasing individualism, participants favoured collective mutually beneficial solutions, with citizenship, rather than family, offering protection from the negative consequences of capitalism (Dumas and Turner, 2009). The politics of intergenerational equity has the potential to devolve into a new variant of austerity politics in which 'fairness' is a question of rationing out a too-small pot of resources among competing deserving groups (Alexander Shaw, 2018), and we identify a belief that state spending is insufficient across all generations. Study participants also advocate for state spending according to need not age. Redistribution along age lines risks exacerbating withingeneration inequalities (Peugny and Van de Velde, 2014; Woodward and Wyn, 2015) and fomenting an ugly form of identity politics that pits generations against each other (Christophers, 2018).

As in many other countries (World Health Organization, 2015; European Commission, 2017), the UK government has implemented a number of policies in an attempt to address concerns around intergenerational unfairness, with a particular focus on increasing home-ownership among younger people. However, in common with other intergenerational 'rebalancing reforms', these respond to existing disequilibria and risk handing resources to the already privileged (Chauvel, 2006). The UK government's Stamp Duty Land Tax changes in England and Northern Ireland are a case-in-point; they have largely served only to increase 
house prices, benefiting existing (generally older) home owners at the expense of (generally younger) first-time buyers (Scanlon et al., 2017).

To explore the causes of generationally based inequalities, Savage (2014: 593) argues for a 'sociology of inheritance', which frames inequalities in the context of Thomas Piketty's detailed and powerful description of the economic fact that in much of recent history the growth in capital/assets has outstripped the growth in income. Christophers (2018: 105) stresses that the economy is not deliberately ageist and to infer that 'the young struggle because they are young, while the older are doing better because they are older' is to miss the central question of how age-associated inequalities are generated. The young are 'collateral damage' in a re-worked economic system that has shifted from a post-war Keynesian welfare state to a neo-liberal individualistic risk society based around the private accumulation of capital (Christophers, 2018: 110). Recent empirical evidence from the UK lends weight to the notion that intergenerational inequalities reflect an economic system in which assets outstrip income and life chances depend heavily on inherited wealth (Resolution Foundation, 2019). If the capital/labour imbalance is the problem, then addressing this must form the solution. In this context, the Resolution Foundation advocates reform of inheritance tax in the UK with the proceeds used to fund a 'citizen's inheritance' of $£ 10,000$ for UK citizens at age 25 . They also suggest strategies to redress the imbalance between wages and capital, including an increased minimum wage, better employment protections and strengthened unions (Resolution Foundation, 2018).

Where we find the greatest intergenerational tensions they had arisen through the starkly differing opinions on the vote to take the UK out of the EU. Younger people identified a symbolic threat from older people based on a perception that older generations' social conservativism and fear of 'the other' had motivated their vote to leave the EU. In time, the perception of a generational cleavage arising from the Brexit vote may pose a new and more serious threat to solidarity between generations. To begin to address this cultural gap, participants expressed a desire for strengthened communities that encouraged greater intergenerational mixing. Perhaps an important facet of the Scottish independence referendum was that it extended the franchise to 16 and 17 year olds. In the UK, youth (aged 18-24) voter turnout levels are among the lowest in the Organisation for Economic Co-operation and Development (OECD) (Gardiner, 2016). Coupled with a demographic imbalance towards older people, younger people lack a voice in UK politics. Suggestions for addressing political disengagement include compulsory voting, online voting and strengthened citizenship education (Gardiner, 2016). Among participants in Edinburgh, there was a belief that the devolved Scottish government represented a more responsive and socially responsible model than the Westminster government. Further, some participants viewed the Scottish independence referendum as an exemplar democratic exercise. Risks to social cohesion could potentially also be addressed by policies that reconnect people to decision-making, such as greater regional devolution.

Finally, a new potential threat to intergenerational solidarity is emerging with the COVID-19 pandemic, which may present a critical turning point in 'the life chances of successive cohorts' (Kendig et al., 2019: 2671)-already the 'Generation COVID-19' label is being applied to young adults aged 16-24 
(Leavey et al., 2020; Rudolph and Zacher, 2020), albeit with researchers cautioning against the application of simplistic generational labels to characterise what is likely to be a period effect (Rudolph and Zacher, 2020). Globally, there is recognition of the immediate and longer-term impacts of pandemic-mitigation strategies on children and young people's education, employment, income and mental health (Green, 2020; OECD, 2020). As with Brexit, there is a danger that the pandemic response will be used to stoke intergenerational tensions. Indeed, sections of the media and some policy think-tanks are suggesting that already-struggling, younger generations are unfairly carrying the burden of a crisis that largely affects alreadyprivileged, older generations (Corfe, 2020; Intergenerational Foundation, 2020). 'Solutions' predictably include reducing older adults' welfare entitlements (Corfe, 2020), including abandoning the so-called pensions 'triple-lock' (Centre for Policy Studies, 2020). The focus on generational inequalities also ignores the unequal burden of the pandemic response placed on women, people from Black, Asian and Minority Ethnic groups, and people living in areas of socio-economic deprivation (Bambra et al., 2020; Burki, 2020).

The strengths of this study lie in its rich qualitative data. However, we acknowledge a number of weaknesses. As with all countries, the UK (this study's location) has its own particular social, economic circumstances and cultural context. While its liberal welfare state is similar to that of the USA and Australia, and its postrecession 'austerity' policies parallel those of many European countries, the Brexit decision is, so far, unique to the UK. Nevertheless, intergenerational equity debates are taking place internationally (Kohli, 2006; European Commission, 2017) and our findings echo those of previous studies conducted in diverse locations, including the USA (Pillemer et al., 2007), Ireland (Timonen et al., 2013; Carney et al., 2014), Australia (Kendig et al., 2019), Germany (Prinzen, 2014) and France (Chauvel, 2006). The study took place in two urban geographical locations and we cannot be certain that people in other areas of the UK would hold similar views. Similarly, a number of groups were underrepresented in our final sample (e.g. men, unemployed people, people belonging to Black, Asian and Ethnic Minority groups, and people who voted to leave the EU in the 2016 referendum).

\section{Conclusion}

Overall, this study reinforces previous research that attests to the prevalence and strength of intergenerational solidarity (Timonen et al., 2013; Kendig et al., 2019). However, in the particular UK context of long-standing austerity measures and major political fault lines that, arguably, have differential consequences depending on age, this study finds widespread pessimism around younger people's futures and evidence of intergenerational ambivalence. This ambivalence was most pronounced around differences of opinion of the vote to take the UK out of the EU. However, research participants of all ages attributed blame not to a generation but to a state ignorant of the realities of people's everyday lives. As has been reinforced by the experiences of the COVID-19 pandemic, social problems are increasingly viewed through a generational lens in ways that potentially foment intergenerational resentment. Generation remains a powerful concept that needs to be addressed if the moral language of 'generationalism' currently being employed by 
elites as a battle line in the fight against the welfare state is not to gain further currency (Timonen et al., 2013; White, 2013).

Acknowledgements. The authors thank the participants for sharing their experiences.

Financial support. This work was supported by Newcastle University's Institute for Ageing and Institute for Social Renewal.

Conflict of interest. The authors declare no conflicts of interest.

Ethical standards. Ethical approval for this study was secured from Newcastle University Faculty of Medical Science Ethics Committee (reference 1295/15278/2017).

\section{References}

Age UK (2014) Agenda for Later Life 2014: Public Policy for Later Life. London: Age UK.

Age UK (2018) Poverty in Later Life. Available at https://www.ageuk.org.uk/globalassets/age-uk/documents/reports-and-publications/reports-and-briefings/money-matters/rb_apr18_poverty_in_later_life.

Alexander Shaw K (2018) Baby Boomers Versus Millennials: Rhetorical Conflicts and Interest-construction in the New Politics of Intergenerational Fairness. UK: European Centre for Progressive Studies.

Ayalon L (2019) Are older adults perceived as a threat to society? Exploring perceived age-based threats in 29 nations. Journals of Gerontology: Psychological Sciences and Social Sciences 74B, 1256-1265.

Ayres R (2014) Demographic differences and voting patterns in Scotland's independence referendum. London: House of Commons Library.

Bambra C, Riordan R, Ford J and Matthews F (2020) The COVID-19 pandemic and health inequalities. Journal of Epidemiology and Community Health 74, 964-968.

Bristow J (2016) The Sociology of Generations: New Directions and Challenges. London: Palgrave Macmillan.

Bristow J (2020) Post-Brexit Boomer blaming: the contradictions of generational grievance. Sociological Review 10.1177/0038026119899882.

Burki T (2020) The indirect impact of COVID-19 on women. The Lancet Infectious Diseases 20, 904-905.

Carney GM, Scharf T, Timonen V and Conlon C (2014) 'Blessed are the young, for they shall inherit the national debt': solidarity between generations in the Irish crisis. Critical Social Policy 34, 312-332.

Centre for Policy Studies (2020) Saving £30 Billion: 9 Simple Steps. London: Centre for Policy Studies.

Charmaz K (2003) Grounded theory. In Smith JA (ed.), Qualitative Psychology: A Practical Guide to Research Methods. London: Sage, pp. 81-110.

Charmaz K (2006) Constructing Grounded Theory: A Practical Guide Through Qualitative Analysis. London: Sage.

Chauvel L (2006) Social generations, life chances and welfare regime sustainability. In Culpepper PD, Hall PA and Palier B (eds), Changing France: The Politics That Markets Make. Basingstoke, UK: Palgrave Macmillan, pp. 150-175.

Christophers B (2018) Intergenerational inequality? Labour, capital, and housing through the ages. Antipode 50, 101-121.

Corfe S (2020) Intergenerational Fairness in the Coronavirus Economy. London: Social Market Foundation.

Cribb J, Hood A and Joyce R (2017) Entering the labour market in a weak economy. Institute for Fiscal Studies, London, IFS Working Paper Series.

Dalzell C (2017) The Demographics of Independence: A Study of Polling on and Since the 2014 Referendum. Scotland:Commonweal.

Department for Work and Pensions (2020) Households Below Average Income: An Analysis of the UK Income Distribution: 1994/95-2018/19. Available at https://assets.publishing.service.gov.uk/government/ uploads/system/uploads/attachment_data/file/875261/households-below-average-income-1994-1995-20182019.pdf.

Dumas A and Turner BS (2009) Aging in post-industrial societies: intergenerational conflict and solidarity. In Hendricks J and Powell J (eds), The Welfare State in Post-industrial Society. New York, NY: Springer, pp. 41-56. 
European Commission (2017) Employment and Social Developments in Europe 2017. European Commission: Luxembourg.

Foster K (2013) Generation and discourse in working life stories. British Journal of Sociology 64, 195-215.

Gardiner L (2016) Votey McVoteface: Understanding the Growing Turnout Gap Between the Generations. London: Resolution Foundation.

Green P (2020) Risks to children and young people during covid-19 pandemic. BMJ 369. doi: https:// doi.org/10.1136/bmj.m1669.

Henderson A and Mitchell J (2015) Scottish Referendum Study.

Hillcoat-Nallétamby S and Phillips JE (2011) Sociological ambivalence revisited. Sociology 45, 202-217.

Holman D and Walker A (2020) Understanding unequal ageing: towards a synthesis of intersectionality and life course analyses. European Journal of Ageing 10.1007/s10433-020-00582-7.

House of Lords (2019) Select Committee on Intergenerational Fairness and Provision. London: The Stationery Office.

Intergenerational Foundation (2020) Covid-19: This is the Moment to Scrap Student Debt. London: Intergenerational Foundation.

International Longevity Centre (2020) Lockdown Not Shutdown-How Can We Unlock the Longevity Dividend Post-pandemic? London: International Longevity Centre UK.

Kendig H, Hussain R, O’Loughlin K and Cannon L (2019) Australian attitudes to intergenerational equity: impacts of social and policy change. Ageing \& Society 39, 2671-2698.

Keohane N (2016) Longer lives, stronger families? London: Social Market Foundation

Kohli M (2006) Aging and justice. In Binstock R, George L, Cutler S, Hendricks J and Schulz J (eds), Handbook of Aging and the Social Sciences. San Diego, CA: Academic Press, pp. 457-475.

Lain D, Airey L, Loretto W and Vickerstaff S (2019) Understanding older worker precarity: the intersecting domains of jobs, households and the welfare state. Ageing \& Society 39, 2219-2241.

Leavey C, Eastaugh A and Kane M (2020) Generation COVID-19: Building the Case to Protect Young People's Future Health. Available at https://www.health.org.uk/publications/long-reads/generationcovid-19.

Mannheim K (1952) The problem of generations. In Kecskemeti P (ed.), Essays on the Sociology of Knowledge. London: Routledge and Kegan Paul, pp. 276-320.

NatCen (2017) How Brexit Has Shaped Our Politics. London: NatCen.

Office for National Statistics (2019) Household Income Inequality, UK: Financial Year Ending 2018. London: Office for National Statistics.

Organisation for Economic Co-operation and Development (OECD) (2020) Youth and COVID-19: Response, Recovery and Resilience. Available at https://read.oecd-ilibrary.org/view/?ref=134_134356ud5kox3g26\&title=Youth-and-COVID-19-Response-Recovery-and-Resilience.

Park SM (2014) Theory of intergenerational ambivalence: is it the perfect new lens for studying intergenerational relationships? Journal of Population Ageing 7, 323-334.

Peugny C and Van de Velde C (2014) Rethinking inter-generational inequality. Revue Française de Sociologie 54, 641-662.

Pillemer K, Suitor JJ, Mock SE, Sabir M, Pardo TB and Sechrist J (2007) Capturing the complexity of intergenerational relations: exploring ambivalence within later-life families. Journal of Social Issues 63, $775-791$.

Prinzen K (2014) Intergenerational ambivalence: new perspectives on intergenerational relationships in the German welfare state. Ageing \& Society 34, 428-451.

Prinzen K (2017) The moral economy of intergenerational redistribution in an ageing society: a qualitative analysis of young adults' beliefs in the United States. Social Policy and Administration 51, 1267-1286.

Prosser C, Fieldhouse EA, Green J, Mellon J and Geoffrey E (2018) Tremors but no youthquake: measuring changes in the age and turnout gradients at the 2015 and 2017 British general elections. Electoral Studies 64. https://dx.doi.org/10.2139/ssrn.3111839.

Purhonen S (2016) Generations on paper: Bourdieu and the critique of 'generationalism'. Social Science Information 55, 94-114.

Rahman F and Tomlinson D (2018) Cross Countries: International Comparisons of Intergenerational Trends. London: Resolution Foundation.

Resolution Foundation (2018) A New Generational Contract. London: Resolution Foundation. 
Resolution Foundation (2019) An Intergenerational Audit for the UK: 2019. London: Resolution Foundation.

Ritchie J, Lewis J, McNaughton Nicholls C and Ormston R (2014) Qualitative Research Practice: A Guide for Social Science Students and Researchers, 2nd Edn. London: Sage.

Rudolph CW and Zacher H (2020) 'The COVID-19 Generation': a cautionary note. Work, Aging and Retirement 6, 139-145.

Savage M (2014) Piketty's challenge for sociology. British Journal of Sociology 65, 591-606.

Scanlon K, Whitehead C and Blanc F (2017) A Taxing Question: Is Stamp Duty Land Tax Suffocating the English Housing Market? London: LSE.

Scharf T, Timonen V, Carney G and Conlon C (2013) Changing Generations: Findings from New Research on Intergenerational Relations in Ireland. Ireland:Irish Centre for Social Gerontology .

Scherger S (2012) Concepts of generation and their empirical application: from social formations to narratives - a critical appraisal and some suggestions. Centre for Research on Socio-cultural Change, Manchester, UK, CRESC Working Paper Series.

Shrimpton H, Skinner G and Hall S (2017) The Millennial Bug: Public Attitudes on the Living Standards of Different Generations. London: Resolution Foundation.

Skinner G and Gottfried G (2016) How Britain Voted in the 2016 EU Referendum. London: Ipsos MORI.

Svallfors S (2008) The generational contract in Sweden: age-specific attitudes to age-related policies. Policy and Politics 36, 381-396.

Timonen V and Conlon C (2015) Beyond Mannheim: conceptualising how people 'talk' and 'do' generations in contemporary society. Advances in Life Course Research 24, 1-9.

Timonen V, Conlon C, Scharf T and Carney G (2013) Family, state, class and solidarity: re-conceptualising intergenerational solidarity through the grounded theory approach. European Journal of Ageing 10, 171-179.

Tucker J (2017) The Austerity Generation: The Impact of a Decade of Cuts on Family Incomes and Child Poverty. London: Child Poverty Action Group.

Vincent JA (2005) Understanding generations: political economy and culture in an ageing society. British Journal of Sociology 56, 4579-4599.

White J (2013) Thinking generations. British Journal of Sociology 64, 216-247.

Williamson J, McNamara T and Howling S (2003) Generational equity, generational interdependence, and the framing of the debate over Social Security reform. Journal of Sociology and Social Welfare 30, 3-14.

Woodman D and Wyn J (2015) Class, gender and generation matter: using the concept of social generation to study inequality and social change. Journal of Youth Studies 18, 1402-1410. http://dx.doi.org/ $10.1080 / 13676261.2015 .1048206$.

World Health Organization (2015) Intergenerational Equity Briefing. Copenhagen: World Health Organization.

YouGov (2017) How Britain Voted at the 2017 General Election. London: YouGov.

YouGov (2019) 2019 General Election: The Demographics Dividing Britain. London: YouGov.

Cite this article: Wildman JM, Goulding A, Moffatt S, Scharf T, Stenning A (2022). Intergenerational equity, equality and reciprocity in economically and politically turbulent times: narratives from across generations. Ageing \& Society 42, 2284-2303. https://doi.org/10.1017/S0144686X21000052 